\title{
Morphine Decreases Social Interaction of Adult Male Rats, While THC Does Not Affect It
}

\author{
R. ŠLAMBEROVÁ ${ }^{1}$, A. MIKULECKÁ ${ }^{2}$, E. MACÚCHOVÁ ${ }^{1}$, I. HREBÍČKOVÁ ${ }^{1}$, \\ M. ŠEVČÍKOVÁ ${ }^{1}$, K. NOHEJLOVÁ ${ }^{1}$, M. POMETLOVÁ ${ }^{1}$
}

${ }^{1}$ Department of Normal, Pathological and Clinical Physiology, Third Faculty of Medicine, Charles University, Prague, Czech Republic, ${ }^{2}$ Department of Developmental Epileptology, Institute of Physiology of the Czech Academy of Sciences, Prague, Czech Republic

Received March 11, 2016

Accepted October 26, 2016

\section{Summary}

The aim of the present study was to compare effect of three low doses of morphine (MOR) and delta9-tetrahydrocannabinol (THC) on social behavior tested in Social interaction test (SIT). $45 \mathrm{~min}$ prior to testing adult male rats received one of the drugs or solvents: MOR $(1 ; 2.5 ; 5 \mathrm{mg} / \mathrm{kg})$; saline as a solvent for MOR; THC $(0.5 ; 1 ; 2 \mathrm{mg} / \mathrm{kg})$; ethanol as a solvent for THC. Occurrence and time spent in specific patterns of social interactions (SI) and non-social activities (locomotion and rearing) was video-recorded for $5 \mathrm{~min}$ and then analyzed. MOR in doses of 1 and $2.5 \mathrm{mg} / \mathrm{kg}$ displayed decreased SI in total. Detailed analysis of specific patterns of SI revealed decrease in mutual sniffing and allo-grooming after all doses of MOR. The highest dose ( $5 \mathrm{mg} / \mathrm{kg}$ ) of MOR decreased following and increased genital investigation. Rearing activity was increased by lower doses of MOR ( 1 and $2.5 \mathrm{mg} / \mathrm{kg}$ ). THC, in each of the tested doses, did not induce any specific changes when compared to matching control group (ethanol). However, an additional statistical analysis showed differences between all THC groups and their ethanol control group when compared to saline controls. There was lower SI in total, lower mutual sniffing and allo-grooming, but higher rearing in THC and ethanol groups than in saline control group. Thus, changes seen in THC and ethanol groups are seemed to be attributed mainly to the effect of the ethanol. Based on the present results we can assume that opioids affect SI more than cannabinoid.

\section{Key words}

Social behavior • Opioids • Morphine • Cannabinoids • THC • Male rats

\section{Corresponding author}

R. Šlamberová, Department of Normal, Pathological and Clinical Physiology, Third Faculty of Medicine, Charles University, Ke Karlovu 4, 12000 Prague 2, Czech Republic. Fax: +420 224902750. E-mail: romana.slamberova@lf3.cuni.cz

\section{Introduction}

Psychotropic drugs are known to have serious influence on humans' as well as animals' behavior (Hayase et al. 2005, Šlamberová 2012, Šlamberová et al. 2014). In humans drugs evoke positive emotions of joy and happiness, or suppress negative states of anxiety or type of depression (Nesse and Berridge 1997, Šlamberová et al. 2015b). Even though drugs of abuse are usually interpreted as socializing substances, because they are often used in dancing clubs and parties, the opposite may be true.

Many studies (Ando et al. 2006, Miczek and Tidey 1989, Trezza et al. 2014), including our own (Šlamberová et al. 2010b, Šlamberová et al. 2015a), repeatedly demonstrate that psychostimulant drugs in rats decrease social behavior. For example acute treatment with high doses of MDMA (3,4-methylenedioxymethamphetamine) inhibits social play behavior (Homberg et al. 2007) and decreases social investigation (Daza-Losada et al. 2009, Maldonado and Navarro 2001, Navarro and Maldonado 1999). Our previous studies have demonstrated that psychostimulants, such as methamphetamine, amphetamine, cocaine and MDMA, suppress social 
interaction (SI) in adult male rats in a dose-specific manner (Šlamberová et al. 2010b, Šlamberová et al. 2015a). Further, we demonstrated that the environmental conditions such as familiarity of the experimental arena and intensity of light play a role in both social and non-social activities (Šlamberová et al. 2010b). While the SI was decreased, locomotion and exploratory rearing were increased in the unfamiliar arena suggesting higher interest in the exploration of the unknown environment without any interest in the conspecific (Šlamberová et al. 2010b).

To extend our previous findings, the present study was targeted on effects of psychostimulants with different mechanism of action on SI in order to extend our previous findings. Therefore, opioids as the "hard" drugs with a rich history and cannabinoids as the "light" drug popular in young people were investigated in the present study.

Animal studies from the ' 80 s and ' 90 s of the past century showed that opioids are very effective in reducing social separation-induced distress vocalizations in pups, they decrease proximity maintenance time in socially housed animals, increase play and decrease maternal aggression (Panksepp et al. 1980). Exposure to morphine (MOR) in utero was shown to increase social play in adolescent rodents (Niesink et al. 1996) and increase appetite, while decreasing effectiveness of sexual behavior (Vathy 1993). On the other hand, our previous study (Šlamberová et al. 2001) demonstrated that MOR administration during the second half of pregnancy attenuates some components of maternal behavior, while increasing other "non-maternal" activities of mothers.

Similarly, cannabinoids have also various effects on social behavior depending on type of cannabinoid drug, dose and test used for evaluation of the effects (Katsidoni et al. 2013). Delta9-tetrahydrocannabinol (THC) affecting cannabinoid CB1 receptors, but not cannabidiol that is inverse agonist of cannabinoid CB2 receptors, reduces contact and aggressive behavior (Klein et al. 2011, van Ree et al. 1984). In addition, O'Shea (2006) demonstrated decreased SI after chronic treatment with the cannabinoid receptor agonist (CP 55 940) following a 28-day drug-free period before the test. Further, Schneider (2008) demonstrated that acute cannabinoid administration induced more deficits in social behavior of pubertal rats than in mature rats.

The aim of the present study was to compare the effect of three low doses of MOR, as a representative of opioids, and three low doses of THC, as a representative of cannabinoids, on social behavior tested in the Social interaction test (SIT).

\section{Methods}

Animals

In total 65 adult male albino Wistar rats (8-9 pair per group) were delivered by Velaz (Prague, the Czech Republic) from Charles River Laboratories International, Inc. Animals were housed four per cage and left undisturbed for a week in a temperature-controlled $\left(22-24^{\circ} \mathrm{C}\right)$ colony room with free access to food and water on a $12 \mathrm{~h}$ (light) : $12 \mathrm{~h}$ (dark) cycle with lights on at 06:00 h.

\section{Social interaction test (SIT)}

Animals (always one animal per time) were first habituated individually in the Open field $(45 \times 45 \times 30 \mathrm{~cm})$ on two consecutive days in a dimly lit room for $10 \mathrm{~min}$ to get familiar with the arena (File and Hyde 1978). On the third day, a pair of unfamiliar animals (each from different home-cage) of the same weight and treatment was tested for SI. The experiment took place in the same condition as habituation. The injection of drug and their vehicles (see below) was applied subcutaneously (s.c.) 45 min prior to the SIT.

The behavior of each pair of animals was videorecorded for $5 \mathrm{~min}$. Subsequently, recordings were evaluated offline by means of ODLog software (Macropod Software). The number (occurrence) and the time spent in SI and non-social behaviors were evaluated. Analyzed parameters were as follows: 1) SI included the following patterns: sniffing (mutual), genital investigation (sniffing the anogenital area), following (the pursuit of one animal by another), climbing over and crawling under the partner and allo-grooming; 2) non-social behavior: locomotion (horizontal exploration) and rearing (vertical exploration).

\section{Drug treatment}

Drugs, MOR $(1.0 ; 2.5 ; 5.0 \mathrm{mg} / \mathrm{kg})$ or THC $(0.5$; $1.0 ; 2.0 \mathrm{mg} / \mathrm{kg}$ ), respectively, were administered s.c. $45 \mathrm{~min}$ prior to SIT. MOR was dissolved in distilled water and THC in ethanol. Control group for MOR received injection of $0.9 \%$ saline and control group for THC $7.2 \%$ ethanol. The administered volume was always $1 \mathrm{ml} / \mathrm{kg}$. These doses were chosen based on our preliminary data showing that these doses do not induce 
stereotypy behavior. The interval of $45 \mathrm{~min}$ was chosen based on our published (Rambousek et al. 2014) and some unpublished pharmacokinetic data showing that the peak of the drugs in the brain (not in the blood) is between $45^{\text {th }}$ and $60^{\text {th }}$ minute after s.c. administration.

\section{Statistical analysis}

Effects of each drug (MOR and THC) were analyzed separately. SI in total was analyzed first, and then the particular patterns of social and non-social behaviors. A One-way ANOVA (drug treatment) with the Bonferroni post-hoc test was used to analyze the time spent in and number of the particular types of social and non-social behaviors. Because no differences were found between THC and their ethanol control, an additional statistical analysis was run to see differences between THC, ethanol and saline control groups. Differences were considered significant if $\mathrm{p}<0.05$.
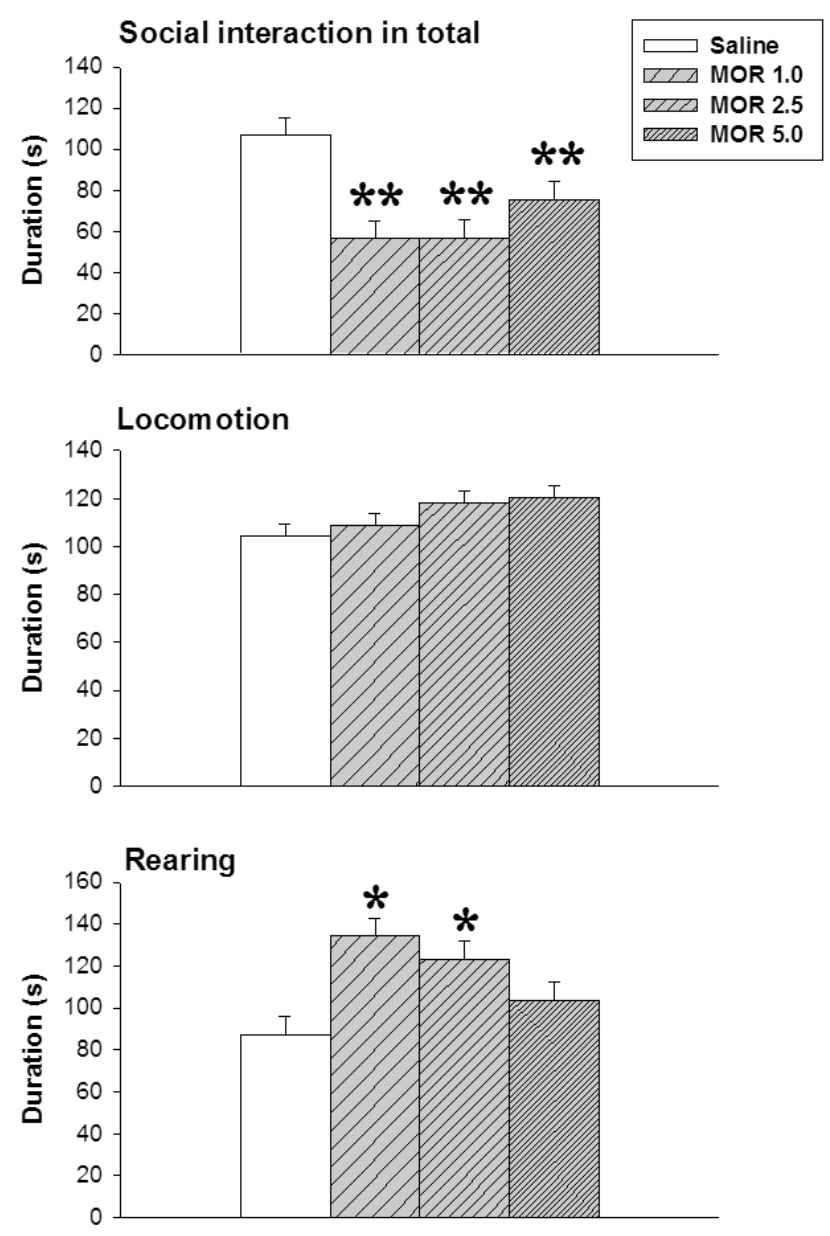

Fig. 1. The effect of morphine on social interaction in total and locomotor and exploratory behavior of adult male rats. Values are mean \pm SEM ( $n=8-9$ pairs). $* p<0.01, * * p<0.001$ vs. saline controls.

\section{Results}

Since the analysis of the number of occurrence of the particular type of behavior yielded highly similar results with the results showing the changes in the time of duration, only data of duration are reported in the graphs.

\section{Morphine}

Social interaction: All doses of MOR decreased the time spent by SI in total relative to saline controls $[F(3,29)=7.76 ; \quad p<0.001] \quad$ (Fig. 1). When analyzing particular patterns (Fig. 2), our data showed that all doses of MOR decreased the time $[F(3,29)=9.16 ; p<0.001]$ as well as number $[F(3,29)=6.74 ; \mathrm{p}<0.05]$ of mutual sniffing and the time $[\mathrm{F}(3,29)=9.10 ; \mathrm{p}<0.001]$ as well as number $[F(3,29)=9.60 ; p<0.001]$ of allo-grooming. Only the highest dose $(5 \mathrm{mg} / \mathrm{kg})$ of MOR decreased the time spent by following $[F(3,29)=3.55 ; \mathrm{p}<0.05]$ and the number of following $[\mathrm{F}(3,29)=4.44 ; \mathrm{p}<0.05]$. In contrast, the time spent by $[\mathrm{F}(3,29)=11.49 ; \mathrm{p}<0.0001]$ and the number $[\mathrm{F}(3,29)=12.31 ; \mathrm{p}<0.0001]$ of genital investigation was increased by the dose of $5 \mathrm{mg} / \mathrm{kg}$ of MOR. Climbing over and crawling under was not affected by MOR.

Non-social activities: As shown in Figure 1, MOR did not affect locomotion, but two lower doses of MOR (1.0 and $2.5 \mathrm{mg} / \mathrm{kg})$ increased the time spent by $[F(3,29)=5.77 ; p<0.01]$ and the number $[F(3,29)=4.17$; $\mathrm{p}<0.05$ ] of rearing when compared to saline controls.

\section{THC}

There were no significant differences in any measure between THC and ethanol groups. Therefore we added also control group administered with saline and run an additional statistical analysis.

Social interaction: All groups of THC as well as ethanol decreased the time spent by SI in total relative to saline controls $[F(4,35)=9.26 ; p<0.0001]$ (Fig. 3). When analyzing particular patterns (Fig. 4), our data showed that all doses of THC as well as ethanol decreased the time $[\mathrm{F}(4,35)=12.79 ; \mathrm{p}<0.0001]$ as well as number $[F(4,35)=9.93 ; p<0.0001]$ of mutual sniffing and the time $[\mathrm{F}(4,35)=10.92 ; \quad \mathrm{p}<0.0001]$ as well as number $[\mathrm{F}(4,35)=13.12 ; \mathrm{p}<0.0001]$ of allo-grooming. There were no differences in any other SI patterns (following, genital investigation, climbing over and crawling under).

Non-social activities: Neither THC, nor ethanol affected locomotion of the animals. On the other hand, the time spent by $[F(4,35)=10.2 ; \mathrm{p}<0.0001]$ and the 

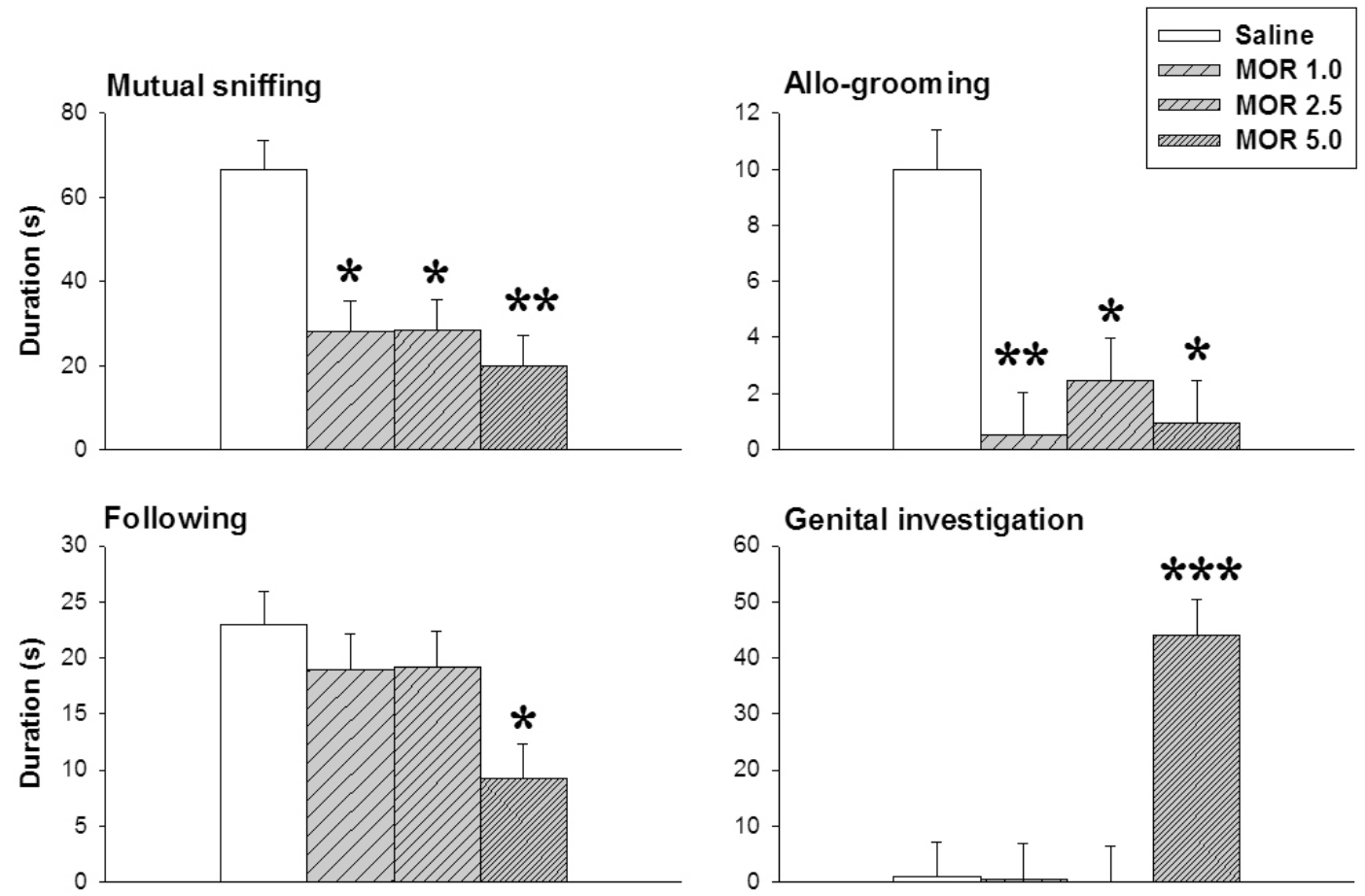

Fig. 2. The effect of morphine on particular patterns of social interaction in adult male rats. Values are mean \pm SEM ( $n=8-9$ pairs). $* \mathrm{p}<0.01, * * \mathrm{p}<0.001$ vs. saline controls.
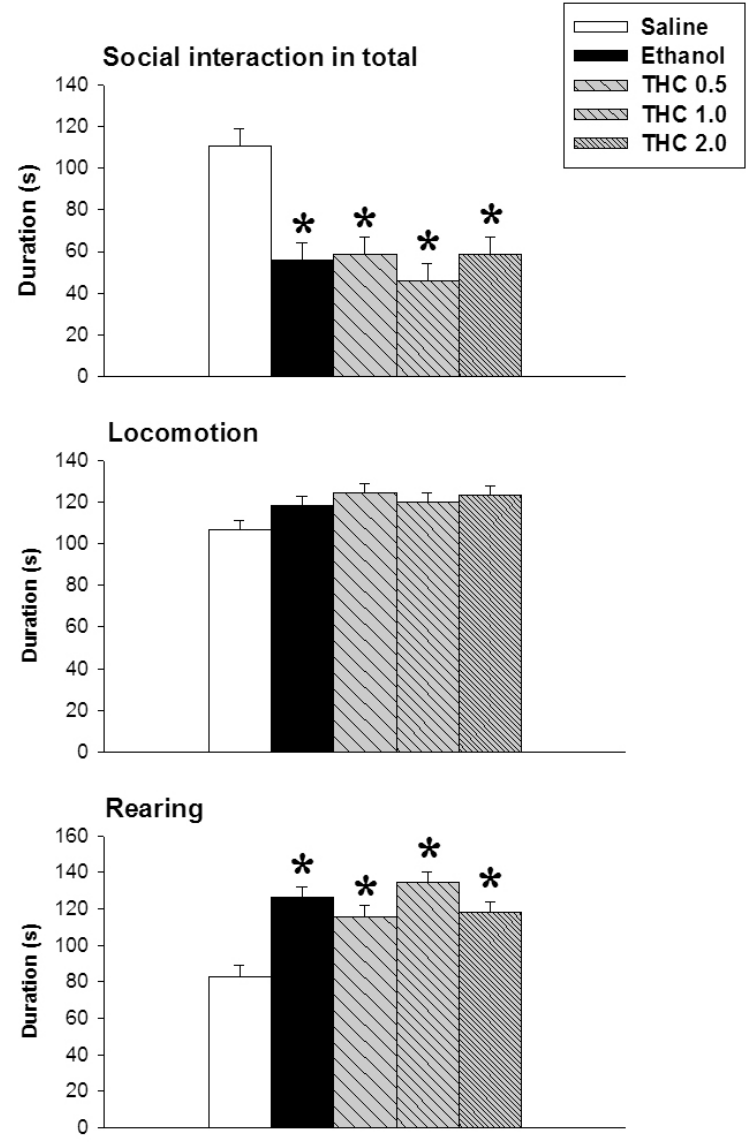

Fig. 3. The effect of THC and ethanol on social interaction in total and locomotor and exploratory behavior of adult male rats. Values are mean \pm SEM ( $n=8-9$ pairs). $* \mathrm{p}<0.01$ vs. saline controls. number $[\mathrm{F}(4,35)=8.94 ; \mathrm{p}<0.0001]$ of rearing was increased after all doses of THC as well as after ethanol relative to saline controls.

\section{Discussion}

The present study demonstrates that both, MOR and ethanol solution of THC, decreased the SI and increased the vertical exploratory behavior, when compared to control group administered with saline. Although, there were no differences in changes of behavior of animals which received THC, when compared to their proper control group - group with ethanol treatment. The explanation for such finding may be several. First, it is possible that the doses of THC (0.5; $1.0 ; 2.0 \mathrm{mg} / \mathrm{kg}$ ) are too low to affect SI itself, excluding effect of ethanol. However, study of Cheer et al. (2000) showing development of positive place preference conditioning by using dose as low as $1.5 \mathrm{mg} / \mathrm{kg}$ of THC disproves this speculation. If such as low dose is able to induce active drug-seeking, which is a sign for drug addiction, it should be enough for affecting also other types of behavior. Second, it is possible that the effect of ethanol, even in low concentration $7.2 \%$ overshadows the effect of THC per se and decreases SI. However, this hypothesis is not supported by studies of Varlinskaya and Spear $(2009,2010)$ showing that ethanol in concentration 

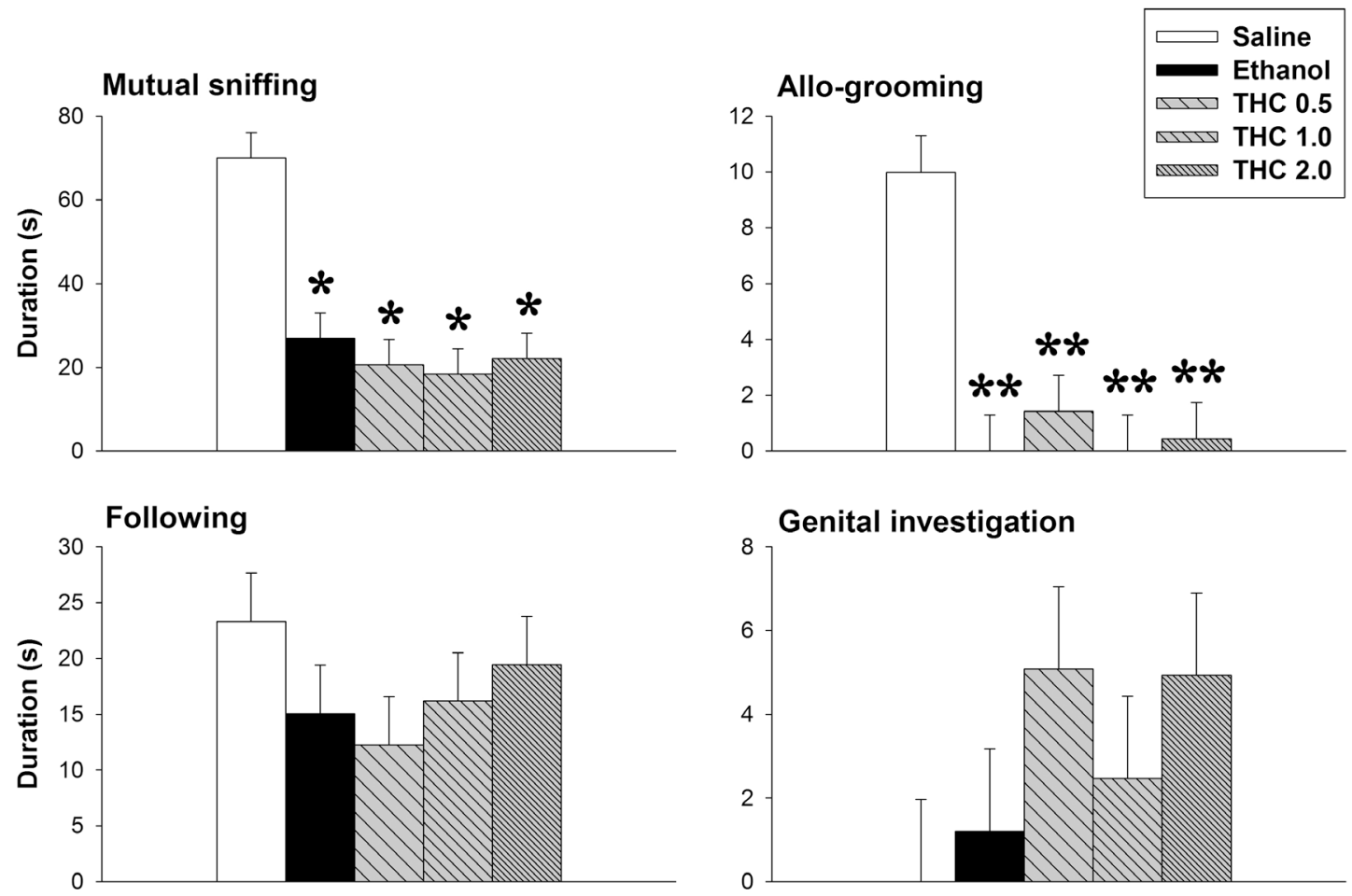

Fig. 4. The effect of THC and ethanol on particular patterns of social interaction in adult male rats. Values are mean \pm SEM ( $\mathrm{n}=8-9$ pairs). $* \mathrm{p}<0.001, * * \mathrm{p}<0.0001$ vs. saline controls.

$12.6 \%$ injected in a dose of 0.5 and $0.75 \mathrm{~g} / \mathrm{kg}$ was pro-socializing. Nevertheless, Trezza et al. $(2009,2014)$ suggested biphasic effect of ethanol; pro-social in lower doses and anti-social in higher doses. However, this is still in contradiction with our results. Third, it is also possible that the reason for the differences seen in the present study are not the effects of the drugs or ethanol, but the effect of saline. Saline administration was repeatedly shown to act as a stressor stimulus when compared to naïve controls without injection (Šlamberová et al. 2010a, Yamamotová et al. 2011). In utero daily saline injections may be considered as prenatal stressor that induces behavioral changes in adult progeny (Peters 1982, Schindler et al. 2004). Moreover, study of Kiyatkin and Lenoir (2011) showed that saline injection is able to produce significant changes in the CNS that may induce desynchronization in EEG rhythm. Thus, one may speculate that not the drugs and ethanol, but the saline injection is responsible for the differences found in the present study. However, this is just a speculation that would need to be verified in future studies that should compare the effect of saline injection with the sham control.

Our results show that MOR treatment decreases both, the time spent in SI as well as the occurrence of SI. Our data contradict the finding of Panksepp et al. (1980) showing that MOR at doses $1 \mathrm{mg} / \mathrm{kg}$ or lower reduced social separation-induced distress vocalizations in pups, decreased the proximity maintenance time in socially housed animals, increased social play and decreased maternal aggression. Also the study of Niesink et al. (1996) showed that MOR $(10 \mathrm{mg} / \mathrm{kg})$ exposure in utero was shown to increase social play in adolescent rodents and increase appetite, while decreasing effectiveness of sexual behavior (Vathy 1993). On the other hand, the present data are supported by our previous findings demonstrating that MOR $(10 \mathrm{mg} / \mathrm{kg})$ administered during the second half of pregnancy attenuates some components of maternal behavior, while increasing other "non-maternal" activities of mothers (Šlamberová et al. 2001). Other our study (Šlamberová et al. 2003) investigating maternal behavior showed that MOR $(10 \mathrm{mg} / \mathrm{kg})$ exposure in utero makes rats better mothers than controls, later on in adulthood. Thus, it seems that not only the dose, but also the timing of MOR exposure (in utero or in adulthood), may diametrically different impact the effect of MOR on social behavior.

All the above mentioned studies tested total SI only, without distinguishing between different social activities as the present study did. In the present set of experiments, detailed evaluation of SI was targeted to specific social behavioral patterns. Specifically, the 
present study demonstrated that mutual sniffing as well as allo-grooming was decreased by all doses of MOR and ethanol/THC. The following of one animal by another was decreased only by the highest dose of MOR, but was not affected by ethanol or THC. The most interestingly, there was high increase of genital investigation after the highest dose $(5 \mathrm{mg} / \mathrm{kg})$ of MOR. Because genital investigation may be considered offensive aggression (Pellis 1988), it is possible that MOR in a dose of $5 \mathrm{mg} / \mathrm{kg}$ can induce aggression. This hypothesis is supported by several findings: MOR had been shown to produce aversion to the odor of pups (Kinsley et al. 1995), increase maternal aggression towards the pups (Haney and Miczek 1989, Rosenblatt et al. 1988) and to increase aggression in a group of adult male rats resulting in destructive and fatal fights (Kanui and Hole 1990). Because in our experimental settings we did not observe any forms of aggressive behaviors such as boxing, aggressive fighting or biting attack, that usually occur in other types of animal modes (e.g. in resident-intruder test), more studies using models of aggression will be necessary to confirm this hypothesis.

As for non-social activities, the present study did not find any differences induced by MOR or THC on locomotion, while there was an increase in vertical exploration (rearing) induced by lower doses of MOR $(1.0$ and $2.5 \mathrm{mg} / \mathrm{kg}$ ) and by ethanol. Non-social activities were not affected by THC treatment when compared to ethanol controls. These data contradict findings showing that THC decreases locomotor activity (HernandezTristan et al. 2000, Schramm-Sapyta et al. 2007). We suggest that the discrepancy might have been caused by a different dose of THC used in our study $(0.5 ; 1.0$; $2.0 \mathrm{mg} / \mathrm{kg}$ ) and the study of Schramm-Sapyta (2007), which was high as $5 \mathrm{mg} / \mathrm{kg}$. This idea is supported by study of Katsidoni et al. (2013) showing dose-dependent effect of THC on locomotion and rearing. Similarly, MOR seems to have dose-dependent effect: while higher doses of MOR $(5 ; 10 ; 15 ; 20 \mathrm{mg} / \mathrm{kg})$ were shown to sedate the animals and decrease their rearing activity (Patti et al. 2005, Šlamberová et al. 2012), lower doses of MOR increase it (Giorgi et al. 1997). The most surprising result of the present study was again the effect of ethanol.
Studies of Varlinskaya and Spear (2009, 2010) showed that ethanol may lower locomotion, however only in a dose of $1.25 \mathrm{~g} / \mathrm{kg}$ (concentration $12.6 \%$ ) but not lower. Similarly also Garcia-Cabrera and Berge (1988) demonstrated that ethanol in a dose of $1.5 \mathrm{~g} / \mathrm{kg}$ depresses spontaneous behavior in rats. This dose is higher than the dose that was used in the present study. In addition, study of Duncan et al. (2000) showed that ethanol in doses of 800 or $1600 \mathrm{mg} / \mathrm{kg}$ increases rearing activity, which is in agreement with the present study. Therefore, also the effect of ethanol on spontaneous behavior seems to be dose-dependent. It is also suggested that the effect of ethanol may be due to the influence on dopaminergic receptors (Rubinstein et al. 1997, Sobrian et al. 2005). Another reason for the differences in locomotion seen in the present study and in the studies of others might be also different method of measure. While the present study measured locomotion as number of occurrence and time spent by the activity, studies of others usually use number of line crossing or walked distance (Hernandez-Tristan et al. 2000, Schramm-Sapyta et al. 2007, Varlinskaya and Spear 2009, Varlinskaya and Spear 2010).

In conclusion, based on the present results we can assume that opioids affect SI in greater extent than cannabinoid. The tested low doses of cannabinoid did not affect evaluated parameters from SIT. This outcome could be the result of ethanol masking an effect of THC. Future studies will examine the effect of ethanol, saline and sham injection on rat behavior.

\section{Conflict of Interest}

There is no conflict of interest.

\section{Acknowledgements}

This study was supported by project \# PRVOUK P34 and project \# 260277/SVV/2016 from Charles University. The procedures for animal experimentation utilized in this report was reviewed and approved by the Institutional Animal Care and Use Committee and is in agreement with the Czech Government Requirements under the Policy of Humans Care of Laboratory Animals (No. 246/1992) and with the regulations of the Ministry of Agriculture of the Czech Republic (No. 311/1997).

\section{References}

ANDO RD, BENKO A, FERRINGTON L, KIRILLY E, KELLY PA, BAGDY G: Partial lesion of the serotonergic system by a single dose of MDMA results in behavioural disinhibition and enhances acute MDMA-induced social behaviour on the social interaction test. Neuropharmacology 50: 884-896, 2006. 
CHEER JF, KENDALL DA, MARSDEN CA: Cannabinoid receptors and reward in the rat: a conditioned place preference study. Psychopharmacology (Berl) 151: 25-30, 2000.

DAZA-LOSADA M, RODRIGUEZ-ARIAS M, MALDONADO C, AGUILAR MA, GUERRI C, MINARRO J: Acute behavioural and neurotoxic effects of MDMA plus cocaine in adolescent mice. Neurotoxicol Teratol 31: 49-59, 2009.

DUNCAN PM, ALICI T, WOODWARD JD: Conditioned compensatory response to ethanol as indicated by locomotor activity in rats. Behav Pharmacol 11: 395-402, 2000.

FILE SE, HYDE JR: Can social interaction be used to measure anxiety? Br J Pharmacol 62: 19-24, 1978.

GARCIA-CABRERA I, BERGE OG: Pressure reversal of the depressant effect of ethanol on spontaneous behavior in rats. Pharmacol Biochem Behav 29: 133-141, 1988.

GIORGI O, CORDA MG, CARBONI G, FRAU V, VALENTINI V, DI CHIARA G: Effects of cocaine and morphine in rats from two psychogenetically selected lines: a behavioral and brain dialysis study. Behav Genet 27 : 537-546, 1997.

HANEY M, MICZEK KA: Morphine effects on maternal aggression, pup care and analgesia in mice. Psychopharmacology (Berl) 98: 68-74, 1989.

HAYASE T, YAMAMOTO Y, YAMAMOTO K: Persistent anxiogenic effects of a single or repeated doses of cocaine and methamphetamine: interactions with endogenous cannabinoid receptor ligands. Behav Pharmacol 16: 395-404, 2005.

HERNANDEZ-TRISTAN R, AREVALO C, CANALS S, LERET ML: The effects of acute treatment with delta9-THC on exploratory behaviour and memory in the rat. J Physiol Biochem 56: 17-24, 2000.

HOMBERG JR, SCHIEPERS OJ, SCHOFFELMEER AN, CUPPEN E, VANDERSCHUREN LJ: Acute and constitutive increases in central serotonin levels reduce social play behaviour in peri-adolescent rats. Psychopharmacology (Berl) 195: 175-182, 2007.

KANUI TI, HOLE K: Morphine induces aggression but not analgesia in the naked mole-rat (Heterocephalus glaber). Comp Biochem Physiol C 96: 131-133, 1990.

KATSIDONI V, KASTELLAKIS A, PANAGIS G: Biphasic effects of Delta9-tetrahydrocannabinol on brain stimulation reward and motor activity. Int J Neuropsychopharmacol 16: 2273-2284, 2013.

KINSLEY CH, MORSE AC, ZOUMAS C, CORL S, BILLACK B: Intracerebroventricular infusions of morphine, and blockade with naloxone, modify the olfactory preferences for pup odors in lactating rats. Brain Res Bull 37 : 103-107, 1995.

KIYATKIN EA, LENOIR M: Intravenous saline injection as an interoceptive signal in rats. Psychopharmacology (Berl) 217: 387-396, 2011.

KLEIN C, KARANGES E, SPIRO A, WONG A, SPENCER J, HUYNH T, GUNASEKARAN N, KARL T, LONG LE, HUANG XF, LIU K, ARNOLD JC, MCGREGOR IS: Cannabidiol potentiates Delta(9)tetrahydrocannabinol (THC) behavioural effects and alters THC pharmacokinetics during acute and chronic treatment in adolescent rats. Psychopharmacology (Berl) 218: 443-457, 2011.

MALDONADO E, NAVARRO JF: MDMA ("ecstasy") exhibits an anxiogenic-like activity in social encounters between male mice. Pharmacol Res 44: 27-31, 2001.

MICZEK KA, TIDEY JW: Amphetamines: aggressive and social behavior. NIDA Res Monogr 94: 68-100, 1989.

NAVARRO JF, MALDONADO E: Behavioral profile of 3,4-methylenedioxy-methamphetamine (MDMA) in agonistic encounters between male mice. Prog Neuropsychopharmacol Biol Psychiatry 23: 327-334, 1999.

NESSE RM, BERRIDGE KC: Psychoactive drug use in evolutionary perspective. Science 278: 63-66, 1997.

NIESINK RJ, VANDERSCHUREN LJ, VAN REE JM: Social play in juvenile rats after in utero exposure to morphine. Neurotoxicology 17: 905-912, 1996.

O'SHEA M, MCGREGOR IS, MALLET PE: Repeated cannabinoid exposure during perinatal, adolescent or early adult ages produces similar longlasting deficits in object recognition and reduced social interaction in rats. J Psychopharmacol 20: 611-621, 2006.

PANKSEPP J, HERMAN BH, VILBERG T, BISHOP P, DEESKINAZI FG: Endogenous opioids and social behavior. Neurosci Biobehav Rev 4: 473-487, 1980. 
PATTI CL, FRUSSA-FILHO R, SILVA RH, CARVALHO RC, KAMEDA SR, TAKATSU-COLEMAN AL, CUNHA JL, ABILIO VC: Behavioral characterization of morphine effects on motor activity in mice. Pharmacol Biochem Behav 81: 923-927, 2005.

PELLIS SM: Agonistic versus amicable targets of attack and defense: consequences for the origin, function, and descriptive classification of play-fighting. Aggress Behav 14: 85-104, 1988.

PETERS DA: Prenatal stress: effects on brain biogenic amine and plasma corticosterone levels. Pharmacol Biochem Behav 17: 721-725, 1982.

RAMBOUSEK L, KAČER P, SYSLOVÁ K, BUMBA J, BUBENÍKOVÁ-VALEŠOVÁ V, ŠLAMBEROVÁ R: Sex differences in methamphetamine pharmacokinetics in adult rats and its transfer to pups through the placental membrane and breast milk. Drug Alcohol Depend 139: 138-144, 2014.

ROSENBLATT JS, MAYER AD, GIORDANO AL: Hormonal basis during pregnancy for the onset of maternal behavior in the rat. Psychoneuroendocrinology 13: 29-46, 1988.

RUBINSTEIN M, PHILLIPS TJ, BUNZOW JR, FALZONE TL, DZIEWCZAPOLSKI G, ZHANG G, FANG Y, LARSON JL, MCDOUGALL JA, CHESTER JA, SAEZ C, PUGSLEY TA, GERSHANIK O, LOW MJ, GRANDY DK: Mice lacking dopamine D4 receptors are supersensitive to ethanol, cocaine, and methamphetamine. Cell 90: 991-1001, 1997.

SCHINDLER CJ, ŠLAMBEROVÁ R, VATHY I: Cholera toxin B decreases bicuculline seizures in prenatally morphine- and saline-exposed male rats. Pharmacol Biochem Behav 77: 509-515, 2004.

SCHNEIDER M: Puberty as a highly vulnerable developmental period for the consequences of cannabis exposure. Addict Biol 13: 253-263, 2008.

SCHRAMM-SAPYTA NL, CHA YM, CHAUDHRY S, WILSON WA, SWARTZWELDER HS, KUHN CM: Differential anxiogenic, aversive, and locomotor effects of $\mathrm{THC}$ in adolescent and adult rats. Psychopharmacology (Berl) 191: 867-877, 2007.

SOBRIAN SK, JONES BL, JAMES H, KAMARA FN, HOLSON RR: Prenatal ethanol preferentially enhances reactivity of the dopamine D1 but not D2 or D3 receptors in offspring. Neurotoxicol Teratol 27: 73-93, 2005.

ŠLAMBEROVÁ R: Drugs in pregnancy: the effects on mother and her progeny. Physiol Res 61: S123-S135, 2012.

ŠLAMBEROVÁ R, SZILAGYI B, VATHY I: Repeated morphine administration during pregnancy attenuates maternal behavior. Psychoneuroendocrinology 26: 565-576, 2001.

ŠLAMBEROVÁ R, BAR N, VATHY I: Long-term effects of prenatal morphine exposure on maternal behaviors differ from the effects of direct chronic morphine treatment. Dev Psychobiol 43: 281-289, 2003.

ŠLAMBEROVÁ R, HRUBÁ L, BERNÁŠKOVÁ K, MATĚJOVSKÁ I, ROKYTA R: Effect of cross-fostering on seizures in adult male offspring of methamphetamine-treated rat mothers. Int J Dev Neurosci 28: 429-435, 2010a.

ŠLAMBEROVÁ R, MIKULECKÁ A, POMETLOVÁ M, SCHUTOVÁ B, HRUBÁ L, DEYKUN K: The effect of methamphetamine on social interaction of adult male rats. Behav Brain Res 214: 423-427, 2010b.

ŠLAMBEROVÁ R, YAMAMOTOVÁ A, POMETLOVÁ M, SCHUTOVÁ B, HRUBÁ L, NOHEJLOVÁ-DEYKUN K, NOVÁ E, MACÚCHOVÁ E: Does prenatal methamphetamine exposure induce cross-sensitization to cocaine and morphine in adult male rats? Prague Med Rep 113: 189-205, 2012.

ŠLAMBEROVÁ R, VRAJOVÁ M, SCHUTOVÁ B, MERTLOVÁ M, MACÚCHOVÁ E, NOHEJLOVÁ K, HRUBÁ L, PUSKARČÍKOVÁ J, BUBENÍKOVÁ-VALEŠOVÁ V, YAMAMOTOVÁ A: Prenatal methamphetamine exposure induces long-lasting alterations in memory and development of NMDA receptors in the hippocampus. Physiol Res 63 (Suppl 4): S547-S558, 2014.

ŠLAMBEROVÁ R, MIKULECKÁ A, MACÚCHOVÁ E, HREBÍČKOVÁ I, ŠEVČÍKOVÁ M, NOHEJLOVÁ K, POMETLOVÁ M: Effects of psychostimulants on social interaction in adult male rats. Behav Pharmacol 26: 776-785, 2015a.

ŠLAMBEROVÁ R, POMETLOVÁ M, MACÚCHOVÁ E, NOHEJLOVÁ K, STUCHLÍK A, VALEŠ K: Do the effects of prenatal exposure and acute treatment of methamphetamine on anxiety vary depending on the animal model used? Behav Brain Res 292: 361-369, 2015b.

TREZZA V, BAARENDSE PJ, VANDERSCHUREN LJ: Prosocial effects of nicotine and ethanol in adolescent rats through partially dissociable neurobehavioral mechanisms. Neuropsychopharmacology 34: 2560-2573, 2009. 
TREZZA V, BAARENDSE PJ, VANDERSCHUREN LJ: On the interaction between drugs of abuse and adolescent social behavior. Psychopharmacology (Berl) 231: 1715-1729, 2014.

VAN REE JM, NIESINK RJ, NIR I: delta 1-Tetrahydrocannabinol but not cannabidiol reduces contact and aggressive behavior of rats tested in dyadic encounters. Psychopharmacology (Berl) 84: 561-565, 1984.

VARLINSKAYA EI, SPEAR LP: Ethanol-induced social facilitation in adolescent rats: role of endogenous activity at mu opioid receptors. Alcohol Clin Exp Res 33: 991-1000, 2009.

VARLINSKAYA EI, SPEAR LP: Sensitization to social anxiolytic effects of ethanol in adolescent and adult SpragueDawley rats after repeated ethanol exposure. Alcohol 44: 99-110, 2010.

VATHY I: Frank A. Beach Award. Sexually dimorphic effects of prenatal morphine and cocaine on adult sexual behavior and brain catecholamines in rats. Horm Behav 27: 1-4, 1993.

YAMAMOTOVÁ A, HRUBÁ L, SCHUTOVÁ B, ROKYTA R, ŠLAMBEROVÁ R: Perinatal effect of methamphetamine on nociception in adult Wistar rats. Int J Dev Neurosci 29: 85-92, 2011. 